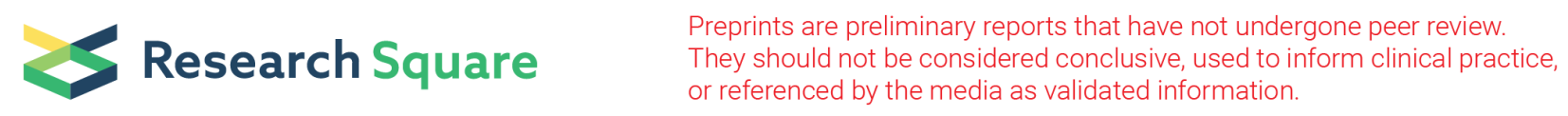

\title{
Paediatric Invasive Pneumococcal Disease : A 5- year Experience and Review of Hospital-Based Studies in Malaysia
}

\section{Research Article}

Keywords:

Posted Date: October 6th, 2020

DOl: https://doi.org/10.21203/rs.3.rs-63493/v2

License: (c) (i) This work is licensed under a Creative Commons Attribution 4.0 International License.

Read Full License 


\section{Abstract}

The authors have requested that this preprint be withdrawn due to author disagreement.

\section{Full Text}

The authors have withdrawn this preprint from Research Square. 